\title{
The Defense Mechanism of Kuhl's Creek Frog (Limnonectes cf. kuhlii)
}

Steven J.R. Allain ${ }^{1}$ and Mark J. Goodman ${ }^{2}$

${ }^{1} 11$ Trafalgar Way, Braintree, Essex, CM7 9UX (steveallain@live.co.uk)

269 Norfolk Street, Cambridge, CB1 2LD (markjamesgoodman@yahoo.com)

W e encountered a number of Kuhl's Creek Frogs (Limnonectes cf. kublii; Fig. 1) during amphibian surveys on Mount Kinabalu, Sabah, Malaysia in SeptemberNovember 2016. Limnonectes kublii (Tschudi 1838) was originally described on Java; however, apparently closely related unnamed species occur throughout tropical southeastern Asia (Frost 2018 and references therein), including Borneo, where they inhabit primary and secondary forests in hilly country from near sea level to 1,600 $\mathrm{m}$ asl (Inger and Stuebing 1997). This was an abundant anuran species at the lower elevations of Mount Kinabalu National Park, second in frequencies of encounters only to the Mountain Litter Frog (Leptobrachium montanum). We found these frogs most frequently along streams and in ditches and roadside drains. They can reach $74 \mathrm{~mm}$ in length and have wide heads and short muscular limbs (Malkmus et al. 2002).

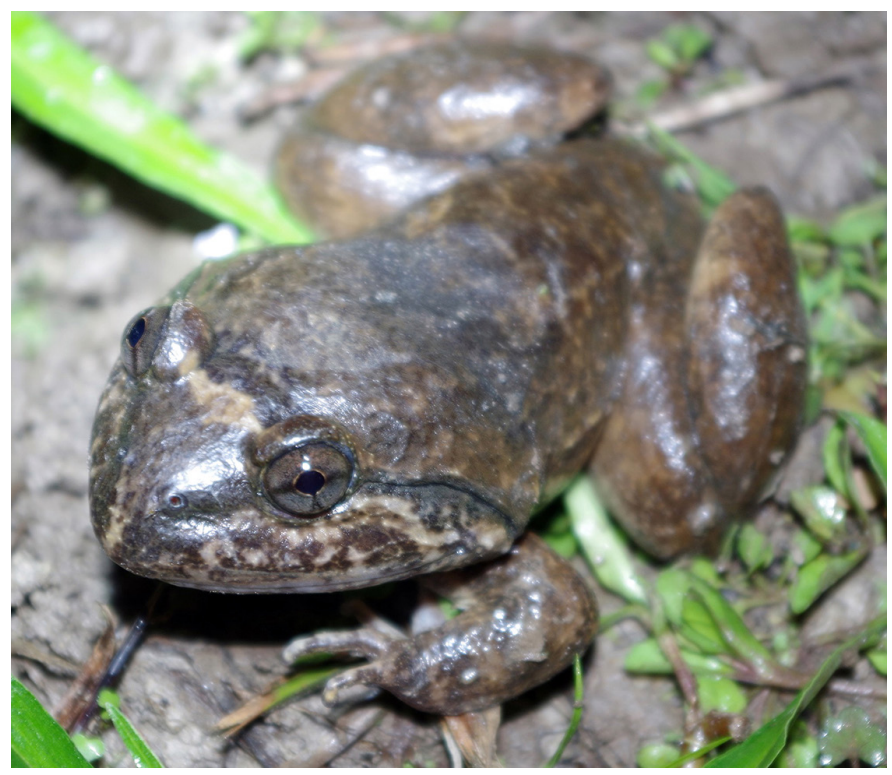

Fig. 1. An adult Kuhl's Creek Frog (Limnonectes cf. kublii) in-situ on the bank of a river in Mount Kinabalu National Park, Sabah, Malaysia. Photograph by Steven J.R. Allain.

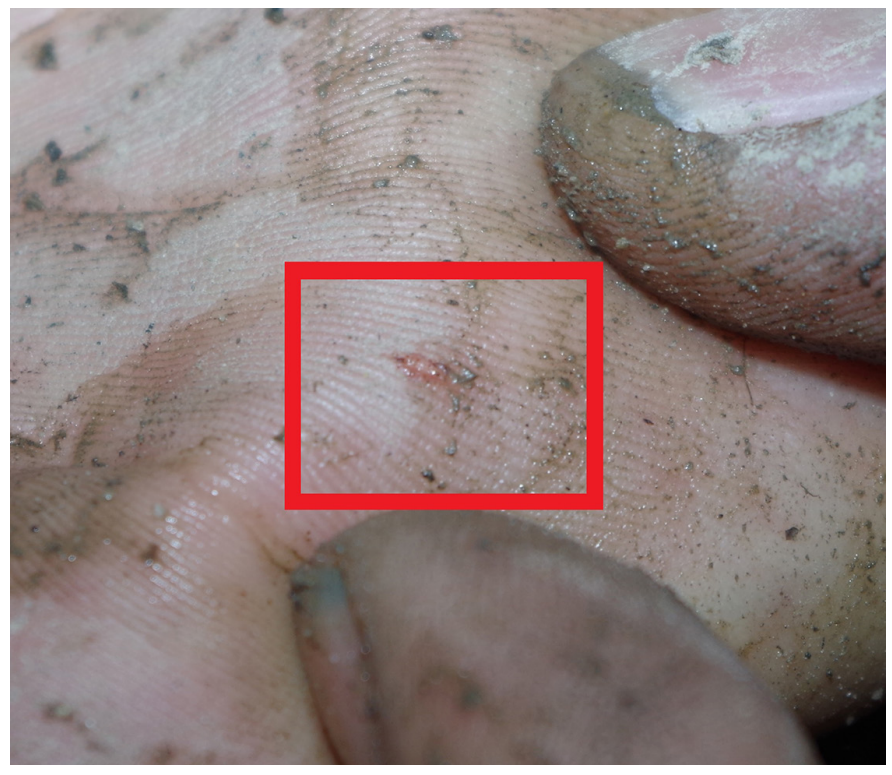

Fig. 2. A wound inflicted by an adult Kuhl's Creek Frog (Limnonectes cf. kublii) (highlighted in red) showing the area where the process pierced the skin. Photograph by Steven J.R. Allain.

When we observed frogs during our night-time visual encounter surveys, we photographed them before taking biometric measurements. For some of the smaller species, this could be done in-situ as they were less likely to flee when measured with a ruler. In most cases, we had to capture individuals of $L$. cf. kublii in order to get an accurate measurement of snout-to-vent length (SVL). While attempting to restrain the frogs, we encountered some unexpected and unusual behavior. At the end of the third toe, these frogs possess a hardened process, which can be used in defense by swinging the hindleg around in a lateral motion (Malkmus et al. 1999). This process is sharp enough to pierce skin and draw blood, which happened on a small number of occasions (Fig. 2). This movement can be used to deter predators and field biologists alike. From our experience, a bony process also may be located on the second digit, attached to the distal phalanges. 
As described by Malkmus et al. (1999), this defense mechanism appears to be present only in larger and mature frogs, and at what stage in the life history it develops is not known. It is not present in subadults, which did not seem to be too stressed by short durations of handling. How this structure evolved is unclear, but it might be linked to the fact that these frogs often bask on banks or in ditches (Malkmus et al. 2002) and are likely to be snatched from the front by predators. This defensive mechanism can be used to encourage predators to release the frogs due to the infliction of both pain and shock.

\section{Literature Cited}

Frost, D.R. 2018. Limnonectes kublii. Amphibian Species of the World: An Online Reference. Version 6.0. American Museum of Natural History, New York (http://research.amnh.org/vz/herpetology/amphibia/Amphibia/Anura/ Dicroglossidae/Dicroglossinae/Limnonectes/Limnonectes-kuhlii).

Inger, R.F. and R.B. Stuebing. 1997. A Field Guide to the Frogs of Borneo. Natural History Publications, Sabah, Borneo.

Malkmus, R., C. Brühl, and T. Eltz. 1999. Amfibieën en reptielen van Deramakot (Sabah, Maleisië). Lacerta 57(6): 191-198.

Malkmus, R., U. Manthey, G. Vogel, P. Hoffmann, and J. Kosuch. 2002. Amphibians \& Reptiles of Mount Kinabalu (North Borneo). ARG Gantner Verlag, Ruggell, Liechtenstein. 